\title{
Asas Keseimbangan dalam Pelaksanaan Perjanjian Anjak Piutang (Factoring)
}

\section{Dewi Astutty Mochtar}

Dewi Astutty Mochtar; Fakultas Hukum Universitas Merdeka Malang; Jl. Raya Dieng 62-64; Malang; 65115; Jawa Timur; Indonesia.

\section{ARTICLEINFO}

Article history:

Received 2019-10-05

Received in revised form

2019-11-04

Accepted 2019-12-01

\section{Kata kunci:}

Asas Keseimbangan; Perjanjian; Anjak Piutang.

\section{Keywords:}

Principle of Equilibrium;

Agreement; Factoring.

DOI: https://doi.org/10.26905/ idjch.v9i2.3558.
Corresponding Author:

* Dewi Astutty Mochtar

E-mail address: dewi.astuty@unmer.ac.id

\section{Abstrak}

Asas keseimbangan bermuatan suatu harapan untuk mencapai keseimbangan termasuk dalam suatu perjanjian atau kontrak bisnis, di mana kepentingan individu bersamaan dijamin oleh hukum yang obyektif, di dalam melaksanakan perjanjian harus ada keseimbangan hak dan kewajiban dari masing-masing pihak sesuai dengan yang diperjanjikan. Sejauh ini pelaksanaan perjanjian anjak piutang (factoring) mengacu pada pasal 1338 KUH Perdata mengikuti prinsip kebebasan untuk membuat kontrak, serta jika ada masalah yang timbul dari lembaga ini, dimungkinkan penyelesaian hukum melalui pengadilan atau melalui arbitrase. Tergantung pada kesepakatan yang dibuat oleh pihak-pihak yang terlibat. Hasil penelitian menunjukkan bahwa sifat hubungan hukum antara factor dan client adalah sifat hubungan hukum dalam bentuk perjanjian pinjam-meminjam, serta adanya kenyataan yang menunjukkan bahwa asas keseimbangan ternyata tidak berlaku pada perjanjian anjak piutang, hal ini disebabkan format dan isi perjanjian ditetapkan secara sepihak oleh factoring, dan tidak dapat dirundingkan lagi oleh debitur. Akibatnya posisi debitur sangat lemah dibandingkan dengan kedudukan kreditur. Asas keseimbangan diperlukan upaya-upaya dari pemerintah dalam bentuk undang-undang yang mengatur tentang aturan-aturan dasar yang harus diperhatikan oleh para pihak yang berkehendak mengadakan perjanjian anjak piutang (factoring).

\section{Abstract}

The principle of equilibrium contains a hope of achieving equilibrium included in an agreement or business contract, where the interests of the individual are guaranteed by objective law, in carrying out the agreement there must be a balance of rights and obligations of each party in accordance with the agreement. So far the implementation of factoring agreement refers to article 1338 of the Civil Code following 


\title{
Asas Keseimbangan dalam Pelaksanaan Perjanjian Anjak Piutang (Factoring)
}

Dewi Astutty Mochtar

\begin{abstract}
the principle of freedom to make a contract, and if there are problems arising from this institution, legal settlement is possible through a court or through arbitration. It depends on the agreement made by the parties involved. The results showed that the nature of the legal relationship between factor and client is the nature of the legal relationship in the form of a loan agreement, and the fact that the principle of balance does not apply to factoring agreements, this is due to the format and content of the agreement unilaterally determined by factoring, and cannot be negotiated again by the debtor. As a result, the debtor's position is very weak compared to the creditor's position. To realize the principle of balance requires efforts from the government in the form of laws governing the basic rules that must be considered by the parties who wish to enter into factoring agreements.
\end{abstract}

\section{Latar Belakang}

Seiring dengan berkembangnya kegiatan bisnis di Indonesia, asas keseimbangan merupakan suatu harapan untuk mencapai keseimbangan termasuk dalam suatu perjanjian atau kontrak, di mana kepentingan individu bersamaan dijamin oleh hukum yang obyektif, termasuk dalam hukum kontrak anjak piutang yang menjadi undangundang bagi pihak-pihak yang terikat dalam kontrak anjak piutang. Asas Keseimbangan merujuk pada pengertian suatu keadaan seimbang yang ditopang dalam ranah filsafat hukum yang menyoroti aktivitas perjanjian anjak piutang yang dinamis. Hal ini terasa harmonis karena perjanjian menganut prinsip pacta sunt servanda (setiap janji harus ditepati) dan itikad baik (good faith).

Eksistensi hukum kontrak dalam perjanjian anjak piutang, seringkali dihubungkan dengan asas keseimbangan, yang mana selalu muncul anggapan bahwa bahwa kontrak yang dibuat oleh para pihak belum memberikan posisi yang seimbang diantara salah satu pihak, sehingga diperlukan adanya temuan baru terkait penyelesaian permsalahan ketidakseimbangan salah satu pihak dalam hubungan kontraktual.

Kenyataan ini menjadikan asas keseimbangan dan hukum kontrak sebagai paduan komplemen yang tidak terpisahkan. Oleh sebab itu selalu dapat ditemukan dalam hukum kontrak penerapan asas keseimbangan, seperti dalam perjanjian bilateral, dalam konvensi-konvensi multilateral, tingkat regional dan internasional di antaranya United $\mathrm{Na}$ tions Convention on Contracts for the International Sale of Goods 1980 dan dalam pendirian World Trade Organization (WTO), yang mana Indonesia telah meratifikasi melalui diundangkannya UndangUndang No. 7 Tahun 1994 tentang Ratifikasi Berdirinya WTO. Dalam undang-undang termaksud dilampirkan kaidah-kaidah hukum yang harus dipedomani negara-negara anggota di era perdagangan bebas tahun 2020 mendatang.

Perjanjian yang telah dibuat melahirkan perikatan yang kemudian menimbulkan hak dan kewajiban diantara para pihak yang membuat perjanjian. Oleh Karen itu, para pihak terikat oleh perjanjian yang telah mereka buat layaknya undangundang dan harus dilaksanakan untuk melaksanakan prestasi pada perjanjian tersebut.

Subekti mengartikan suatu perjanjian sebagai suatu peristiwa dimana seseorang berjanji kepada orang lain atau dimana dua orang itu saling berjanji untuk melaksanakan suatu hal (Subekti, 1983). Perjanjian berdasarkan berupa suatu rangkaian perkataan yang mengandung janji-janji atau kesanggupan yang diucapkan atau ditulis. Sedangkan perikatan adalah suatu perhubungan hukum antara dua orang atau dua pihak, berdasarkan yang mana 


\section{Jurnal Cakrawala Hukum, Volume 10 No. 2 Desember 2019}

ISSN PRINT 2356-4962 ISSN ONLINE 2598-6538

pihak yang satu berhak menuntut sesuatu hal dari pihak yang lain, dan pihak yang lain berkewajiban untuk memenuhi tuntutan itu.

Pelaksanaan perkembangan perjanjian anjak piutang banyak mengalami kendala, hal ini disebabkan kegiatan anjak piutang belum diatur secara khusus pada peraturan perundang-undangan, kegiatan anjak piutang didasarkan azas kebebasan berkontrak dalam Kitab Undang-Undang Hukum Perdata yang diatur pada pasal 1338 KUH Perdata. Menurut ketentuan pasal 1338 KUH Perdata, keberadaan suatu perjanjian atau yang saat ini dikenal sebagai kontrak, tidak terlepas dari terpenuhinya syarat-syarat mengenai sahnya suatu perjanjian/kontrak seperti yang tercantum dalam pasal 1320 KUHPerdata.

Konsep keseimbangan begitu penting dalam penyusunan suatu kontrak karena tahapan inilah yang menjadi dasar dalam pemenuhan prestasi. Konsep keseimbangan dituangkan menjadi suatu asas hukum dalam hukum kontrak yakni asas keseimbangan. Asas hukum berfungsi sebagai pondasi yang memberikan arah, tujuan serta penilaian fundamental, mengandung nilai-nilai dan tuntutantuntutan etis. (Raharjo, 2000)

Asas keseimbangan sangat berperan dalam menentukan posisi dari para pihak. Posisi para pihak harus diupayakan seimbang dalam menentukan hak dan kewajiban dari para pihak. Asas keseimbangan dalam kontrak dapat dilihat pada bagian menimbang dalam suatu kontrak. Bagian menimbang ini merupakan representasi dari adanya offer atau penawaran dan acceptance atau penerimaan.

Oleh karena itu, apabila terdapat posisi yang tidak seimbang di antara para pihak, maka hal ini harus ditolak karena akan berpengaruh terhadap substansi maupun maksud dan tujuan dibuatnya kontrak itu, ialah (Hernoko, 2010): a) lebih mengarah pada keseimbangan posisi para pihak, artinya dalam hubungan kontraktual tersebut posisi para pihak diberi muatan keseimbangan; b) kesamaan pembagian hak dan kewajiban dalam hubungan kontraktual seolah-olah tanpa memperhatikan proses yang berlangsung dalam penentuan hasil akhir pembagian tersebut; c) keseimbangan seolah sekadar merupakan hasil akhir dari sebuah proses; d) intervensi negara merupakan instrumen memaksa dan mengikat agar terwujud keseimbangan posisi para pihak; e) pada dasarnya keseimbangan posisi para pihak hanya dapat dicapai pada syarat dan kondisi yang sama (ceteris paribus).

Anjak piutang dalam pelaksanaan perjanjian jual beli maka ia tunduk kepada ketentuan mengenai perjanjian jual beli yang diatur dalam Pasal 1457 sampai dengan Pasal 1540 Bab ke-V Buku Ketiga Tentang Perikatan KUH Perdata. Selain itu dikarenakan dalam jual beli tindakan selanjutnya adalah levering maka perlu diperhatikan Pasal 613 KUH Perdata. Objek jual beli dalam perjanjian anjak piutang adalah piutang dagang yang merupakan benda bergerak tak bertubuh (intangible moveable goods) maka perlu diperhatikan ketentuan-ketentuan dalam Bab ke-VI dan Ke-VII Buku Kesatu KUHD.

Kegiatan anjak piutang, tingkat kepercayaan factor terhadap client sangat rendah. Namun, karena posisi factor yang kuat maka dalam kontrak anjak piutang banyak dituangkan klausul-klausul yang merupakan perwujudan kehendak factor guna memberikan perlindungan kepada factor dari resiko kerugian usaha.

Sehingga perlu adanya Undang-Undang yang mengatur secara khusus aturan anjak piutang ini. Dan perlunya harmonisasi prinsip-prinsip hukum kontrak internasional yang telah diluncurkan oleh UNIDROIT, International Institute for the Unification of Private Law. Dengan harapan prinsip-prinsip internasional ini diakomodir sebagai hukum positif untuk membatasi asas kebebasan berkontrak.

Beberapa prinsip internasional UNIDROIT yang dimaksud adalah keseimbangan dan keterbukaan. Artinya, harus ada keseimbangan antara 


\section{Asas Keseimbangan dalam Pelaksanaan Perjanjian Anjak Piutang (Factoring)}

Dewi Astutty Mochtar

factor dengan client. Sehingga posisi client tidak lagi berada di bawah factor. Selain itu, prinsip keterbukaan juga perlu dimasukan agar sesama pihak saling memahami kondisinya. Hal ini terkait dengan prinsip itikad baik dan transaksi jujur.

Melaksanakan perjanjian harus ada keseimbangan hak dan kewajiban dari masing-masing pihak sesuai dengan yang diperjanjikan. Asas keseimbangan merupakan hal terpenting di dalam suatu perjanjian. Dari penelitian tersebut dapat disimpulkan bahwa tidak ada perlindungan hukum bagi pihak client serta menganalisa klausulklausul yang terdapat dalam perjanjian anjak piutang tersebut tidak mengandung asas keseimbangan.

\section{Metode}

Jenis penelitian yang dilakukan disini adalah penelitian hukum normatif, yaitu penelitian hukum yang menggunakan sumber data sekunder dan menitikberatkan berlakunya perundang-undangan sebagai hukum positif. Penelitian hukum normatif yang digunakan dalam penelitian ini adalah penelitian yang mengkaji pada konsep hukum tentang anjak piutang, norma hukum mengenai anjak piutang yang berkaitan dengan perlindungan hukum terhadap klien pada perjanjian anjak piutang serta asas keseimbangan pada kontrak baku dalam perjanjian anjak piutang.

\section{Pembahasan}

\subsection{Eksistensi Asas Keseimbangan dalam Pelak-} sanaan Perjanjian Anjak Piutang (Factoring)

Setiap perusahaan mempunyai berbagai kegiatan bisnis seperti kegiatan utama atau operasional perusahaan dan kegiatan yang di luar operasionalnya. Perusahaan harus mengelola kegiatan tersebut dengan baik agar tidak menghambat kegiatan yang lain. Salah satu operasional perusahaan adalah penjualan barang atau jasa, baik yang dilakukan secara atau kredit yang dilaksanakan sesuai dengan perjanjian. Perjanjian jual beli lahir dan mengikat setelah adanya kata sepakat dari para pihak mengenai harga dan barang atau jasa walaupun belum dilakukan penyerahan barang atau jasa dan pembayaran harga.

Jika dilakukan secara tunai maka perusahaan tersebut akan langsung menikmati keuntungannya tetapi jika dilakukan secara kredit maka perusahaan tersebut akan mempunyai piutang atau tagihan yang bagi perusahaan akan memperlambat arus kas (cash in flow) karena dana tunai atau kas baru akan masuk setelah piutang tersebut jatuh tempo, sehingga perusahaan harus menggunakan manajemen yang baik secra efektif dan efisien agar piutang tersebut dapat ditagih sesuai dengan harapan yang diinginkan.

Ketika terjadi kemacetan dalam penagihan piutang, perusahaan akan mengalami kerugian yang besar karena terganggunya perputaran barang atau jasa sehingga berpengaruh terhadap perputaran keuangan (cash in flow). Salah satu alternatif untuk memperoleh dana tunai adalah dengan menjual atau mengalihkan faktur-faktur piutang yang dimilikinya ke Lembaga Keuangan Anjak Piutang.

Kenyataannya memang sulit untuk dapat melihat suatu keadaan yang sama antara para pihak yang terlibat, khususnya dalam hal anjak piutang, akan tetapi ketidak samaan tersebut tidak boleh dimanfaatkan oleh pihak dominan untuk memaksakan kehendaknya kepada pihak lain, dalam situasi semacam inilah asas keseimbangan bermakna equitability.

Keberhasilan perusahaan dalam kegiatan bisnisnya ditentukan oleh perjanjian yang dibuat dan disusun oleh para pihak. Sebagai suatu proses, perjanjian atau kontrak yang ideal seharusnya bisa menjembatani pertukaran kepentingan para pihak secara adil dan jujur pada setiap tahapan perjanjian atau kontrak. Kesepakatan dalam perjanjian atau kontrak merupakan salah satu penerapan asas keseimbangan dalam hal pembuatan perjanjian 


\section{Jurnal Cakrawala Hukum, Volume 10 No. 2 Desember 2019}

ISSN PRINT 2356-4962 ISSN ONLINE 2598-6538

untuk merumuskan pertukaran hak dan kewajiban para pihak yang harus dipenuhi.

Mengenai eksistensi perjanjian anjak piutang dalam hubungannya dengan para pihak sering dikaitkan dengan keseimbangan dalam berkontrak yang memenuhi asas keseimbangan. Tetapi yang terjadi dalam pelaksanaannya muncul anggapan bahwa perjanjian yang terjadi antara para pihak tidak memberikan keseimbangan posisi bagi salah satu pihak. Perjanjian ini mengakibatkan anggapan tidak adil dan berat sebelah, sehingga menimbulkan upaya untuk dapat menyelesaikan masalah ketidakseimbangan dalam hubungan kontraktual.

Asas keseimbangan juga dipahami sebagai keseimbangan kedudukan posisi tawar para pihak dalam menentukan hak dan kewajibannya dalam perjanjian. Ketidakseimbangan posisi menimbulkan ketidakadilan, sehingga perlu intervensi pemerintah untuk melindungi pihak yang lemah melalui penyeragaman syaratsyarat perjanjian.

Prakteknya klausul yang dibuat oleh para pihak di dalam perjanjian anjak piutang tersebut ditentukan sepihak oleh faktor tanpa melibatkan pihak klien sebagai penjual. Pihak klien juga tidak diberi kesempatan untuk menyampaikan kehendaknya yaitu menerima atau menolak klausul tersebut.

Sehingga timbul tidak adanya kesepakatan bagi pihah klien. Pihak klien hanya memiliki pilihan menerima semua syarat dan ketentuan yang telah ditetapkan oleh pihak faktor dan menandatangani perjanjian tersebut, atau menolak perjanjian tersebut. Kebebasan yang diberikan oleh undangundang dapat dimanfaatkan oleh pihak factor untuk menyusun klausul-klausul yang menguntungkan bagi pihak faktor dan sebaliknya merugikan bagi pihak klien.

Belum adanya aturan yang menjadi dasar hukum yang mengatur tentang kegiatan anjak piutang di Indonesia juga mempengaruhi belum berkembangnya anjak piutang sebagai alternatif pembiayaan bagi dunia usaha. Saat ini baru ada Per- aturan Presiden Nomor 9 Tahun 2009 tentang Lembaga Pembiayaan dan Peraturan Menteri Keuangan Nomor 84/PMK.012/2006 tentang Perusahaan Pembiayaan yang dipakai sebagai acuan oleh pelaku kegiatan pembiayaan Anjak.

Piutang, sementara itu untuk pengaturan mengenai perjanjiannya mengacu pada KUH Perdata Pasal 1338 yang merujuk pada asas kebebasan berkontrak yang sering kali dikaitkan dengan asas keseimbangan, sehingga para pihak dalam membuat aturan perjanjian dilakukan dengan kesepakatan begitu juga jika ada permasalahan yang timbul maka para pihak mencari solusi penyelesaian berdasarkan kesepakatan artinya bisa dilakukan melalui pengadilan negeri maupun melalui lembaga arbitrase.

Berdasarkan pedoman pada ketentuan perundang-undangan yang ada, berikut ini eksistensi asas keseimbangan dalam perjanjian anjak piutang: 1) Klausul Terminologi dan Definisi; 2) Klausul Penawaran Piutang; 3) Klausul Pengalihan Piutang; 4) Klausul Harga Piutang Klien.

Dengan memperhatikan beberapa klausul di atas bagi para pihak yang mengadakan perjanjian anjak piutang sangat beralasn untuk mencantumkan beberapa klausul tersebut yang sesuai dengan kehendak para pihak sehingga tercipta keseimbangan pembagian antara hak dan kewajiban. Dengan membaca kalusul kontrak di atas timbul asumsi bahwa beberapa klausul tersebut hanya melindungi salah satu pihak, hal ini dikarenakan perjanjian anjak piutang yang berbentuk kontrak baku tidak memenuhi asas keseimbangan.

Asas keseimbangan ini sulit diterapkan dalam lembaga pembiayaan anjak piutang dengan alasan menjaga eksistensi perusahaan lembaga pembiayaan yang dibutuhkan masyarakat. Dalam rangka menyeimbangkan kedudukan para pihak maka upaya implementasi asas kesimbangan ini dapat ditemukan dalam pelaksanaan perjanjian anjka piutang dalam peraturan perundang-undangan dan kebiasaan internasional yang berhubungan dengan penyelenggaraan anjak piutang (factoring). 


\section{Asas Keseimbangan dalam Pelaksanaan Perjanjian Anjak Piutang (Factoring)}

Dewi Astutty Mochtar

Asas kesimbangan didasarkan pada upaya mencapai suatu keadaan seimbang, sebagai akibatnya harus memunculkan pengalihan kekayaan secara sah. Untuk menganalisis keseimbangan hubungan di antara para pihak tidak ditentukan oleh kesamaan jumlah klausul yang ada, namun yang lebih penting adalah hak dan kewajiban di antara para pihak telah mencapai keseimbangan dan kesepakatan. Jika dilakukan secara tunai maka perusahaan tersebut akan langsung menikmati keuntungannya tetapi jika dilakukan secara kredit maka perusahaan tersebut akan mempunyai piutang atau tagihan yang bagi perusahaan akan memperlambat arus kas (cash in flow) karena dana tunai atau kas baru akan masuk setelah piutang tersebut jatuh tempo, sehingga perusahaan harus menggunakan manajemen yang baik secra efektif dan efisien agar piutang tersebut dapat ditagih sesuai dengan harapan yang diinginkan.

Ketika terjadi kemacetan dalam penagihan piutang, perusahaan akan mengalami kerugian yang besar karena terganggunya perputaran barang atau jasa sehingga berpengaruh terhadap perputaran keuangan (cash in flow). Salah satu alternatif untuk memperoleh dana tunai adalah dengan menjual atau mengalihkan faktur-faktur piutang yang dimilikinya ke Lembaga Keuangan Anjak Piutang.

Suatu keadaan yang sama antara para pihak yang terlibat, khususnya dalam hal anjak piutang, akan tetapi ketidak samaan tersebut tidak boleh dimanfaatkan oleh pihak dominan untuk memaksakan kehendaknya kepada pihak lain, dalam situasi semacam inilah asas keseimbangan bermakna equitability.

Keberhasilan perusahaan dalam kegiatan bisnisnya ditentukan oleh perjanjian yang dibuat dan disusun oleh para pihak. Sebagai suatu proses, perjanjian atau kontrak yang ideal seharusnya bisa menjembatani pertukaran kepentingan para pihak secara adil dan jujur pada setiap tahapan perjanjian atau kontrak. Kesepakatan dalam perjanjian atau kontrak merupakan salah satu penerapan asas keseimbangan dalam hal pembuatan perjanjian untuk merumuskan pertukaran hak dan kewajiban para pihak yang harus dipenuhi.

Mengenai eksistensi perjanjian anjak piutang dalam hubungannya dengan para pihak sering dikaitkan dengan keseimbangan dalam berkontrak yang memenuhi asas keseimbangan. Tetapi yang terjadi dalam pelaksanaannya muncul anggapan bahwa perjanjian yang terjadi antara para pihak tidak memberikan keseimbangan posisi bagi salah satu pihak. Perjanjian ini mengakibatkan anggapan tidak adil dan berat sebelah, sehingga menimbulkan upaya untuk dapat menyelesaikan masalah ketidakseimbangan dalam hubungan kontraktual.

Asas keseimbangan juga dipahami sebagai keseimbangan kedudukan posisi tawar para pihak dalam menentukan hak dan kewajibannya dalam perjanjian. Ketidakseimbangan posisi menimbulkan ketidakadilan, sehingga perlu intervensi pemerintah untuk melindungi pihak yang lemah melalui penyeragaman syaratsyarat perjanjian.

Prakteknya klausul yang dibuat oleh para pihak di dalam perjanjian anjak piutang tersebut ditentukan sepihak oleh faktor tanpa melibatkan pihak klien sebagai penjual. Pihak klien juga tidak diberi kesempatan untuk menyampaikan kehendaknya yaitu menerima atau menolak klausul tersebut.

Sehingga timbul tidak adanya kesepakatan bagi pihah klien. Pihak klien hanya memiliki pilihan menerima semua syarat dan ketentuan yang telah ditetapkan oleh pihak faktor dan menandatangani perjanjian tersebut, atau menolak perjanjian tersebut. Kebebasan yang diberikan oleh undangundang dapat dimanfaatkan oleh pihak factor untuk menyusun klausul-klausul yang menguntungkan bagi pihak faktor dan sebaliknya merugikan bagi pihak klien.

Belum adanya aturan yang menjadi dasar hukum yang mengatur tentang kegiatan anjak 


\section{Jurnal Cakrawala Hukum, Volume 10 No. 2 Desember 2019}

ISSN PRINT 2356-4962 ISSN ONLINE 2598-6538

piutang di Indonesia juga mempengaruhi belum berkembangnya anjak piutang sebagai alternatif pembiayaan bagi dunia usaha. Saat ini baru ada Peraturan Presiden Nomor 9 Tahun 2009 tentang Lembaga Pembiayaan dan Peraturan Menteri Keuangan Nomor 84/PMK.012/2006 tentang Perusahaan Pembiayaan yang dipakai sebagai acuan oleh pelaku kegiatan pembiayaan Anjak.

Piutang, sementara itu untuk pengaturan mengenai perjanjiannya mengacu pada KUH Perdata Pasal 1338 yang merujuk pada asas kebebasan berkontrak yang sering kali dikaitkan dengan asas keseimbangan, sehingga para pihak dalam membuat aturan perjanjian dilakukan dengan kesepakatan begitu juga jika ada permasalahan yang timbul maka para pihak mencari solusi penyelesaian berdasarkan kesepakatan artinya bisa dilakukan melalui pengadilan negeri maupun melalui lembaga arbitrase.

Berdasarkan pedoman pada ketentuan perundang-undangan yang ada, berikut ini eksistensi asas keseimbangan dalam perjanjian anjak piutang: 1) Klausul Terminologi dan Definisi; 2) Klausul Penawaran Piutang; 3) Klausul Pengalihan Piutang; 4) Klausul Harga Piutang Klien.

Dengan memperhatikan beberapa klausul di atas bagi para pihak yang mengadakan perjanjian anjak piutang sangat beralasn untuk mencantumkan beberapa klausul tersebut yang sesuai dengan kehendak para pihak sehingga tercipta keseimbangan pembagian antara hak dan kewajiban. Dengan membaca kalusul kontrak di atas timbul asumsi bahwa beberapa klausul tersebut hanya melindungi salah satu pihak, hal ini dikarenakan perjanjian anjak piutang yang berbentuk kontrak baku tidak memenuhi asas keseimbangan.

Asas keseimbangan ini sulit diterapkan dalam lembaga pembiayaan anjak piutang dengan alas an menjaga eksistensi perusahaan lembaga pembiayaan yang dibutuhkan masyarakat. Dalam rangka menyeimbangkan kedudukan para pihak maka upaya implementasi asas kesimbangan ini dapat ditemukan dalam pelaksanaan perjanjian anjka piutang dalam peraturan perundang-undangan dan kebiasaan internasional yang berhubungan dengan penyelenggaraan anjak piutang (factoring).

Asas kesimbangan didasarkan pada upaya mencapai suatu keadaan seimbang, sebagai akibatnya harus memunculkan pengalihan kekayaan secara sah. Menganalisis keseimbangan hubungan di antara para pihak tidak ditentukan oleh kesamaan jumlah klausul yang ada, namun yang lebih penting adalah hak dan kewajiban di antara para pihak telah mencapai keseimbangan dan kesepakatan.

\subsection{Perjanjian Anjak Piutang (Factoring) yang Sesuai Bagi Kehendak Para Pihak}

Setiap perjanjian atau kontrak mencerminkan adanya kesesuaian kehendak dari para pihak untuk memenuhi kebutuhannya. Pada kenyataannya akan dijumpai banyak kebutuhan berbeda yang menjadi landasan transaksi untuk diwujudkan dalam sebuah perjanjian Terkait dengan hal tersebut, salah satu yang menentukan keberhasilan dalam bisnis juga ditentukan oleh struktur dan bangunan perjanjian atau kontrak yang dibuat oleh para pihak, sebagai suatu proses perjanjian atau kontrak yang ideal seharusnya bisa menjembatani pertukaran kepenüngan para pihak secara seimbang.

Terkait dengan kondisi tersebut, maka ada tahapan penting yang harus dilalui para pihak di dalam proses pembentukan perjanjian atau kontrak yaitu negosiasi. Dalam setiap proses negosiasi perjanjian atau kontrak tujuan para pihak sebenarnya hanya satu, yaitu untuk mencapai kata sepakat (Kusumohamidjojo, 1999). Melalui negosiasi proses pertukaran kepentingan diantara para pihak berjalan sesuai dengan dinamika perjanjian yang bersangkutan, artinya para pihak dihadapkan pada dua karakteristik negosiasi kontrak, yaitu sifat positif dan sifat negaif.

Menurut Budiono Kusumohamidjojo (1999) negosiasi bersifat positif atau negatif bukannya 


\section{Asas Keseimbangan dalam Pelaksanaan Perjanjian Anjak Piutang (Factoring)}

Dewi Astutty Mochtar

karena negosiasi itu dapat bersifat baik atau buruk Seharusnya tidak ada negosiasi yang bersifat baik atau buruk, suatu negosiasi akan bermuara pada keberhasilan atau kegagalan. Suatu kesepakatan perjanjian bersifat positif jika para pihak hendak mencapai suatu perjanjian yang bersifat kerja sama. Iükad baik dari para pihak sebagai dasar untuk melakukan negosiasi harus bersifat timbal balik. Sedangkan menurut Garry Goodpaster negosiasi adalah proses bekerja untuk mencapai suatu perjanjian dengan pihak lain, suatu proses interaksi dan komunikasi yang sama dinamis dan variansinya, serta halus bernuansa, sebagaimana keadaan atau yang dapat dicapai orang (Goodpaster, 1999).

Donald G. Gifford (1999) melibatkan pihakpihak menyatakan bahwa negosiasi merupakan suatu proses yang mencapai kata sepakat untuk sating tukar sesuatuyang diinginkan pihak lain melalui proses tawar menawar, baik mengenai halhal yang muncul Pada situasi aktual, ketidaksepakatan maupun konflik yang potensial muncul dan berkembang.

Jeremy G. Thorn (1995) dalam mempertimbangkan suatu negosiasi akan dilakukan pada umumnya diterapkan syarat-syarat sebagai berikut: a) Kedua belah pihak akan melakukan suatu perjanjian; b) terdapat perjanjian diantara beberapa pihak; c) Terdapat variabel untuk dipertukarkan melalui konsesi; d) Kedua pihak mempunyai wewenang untuk mengubah syarat-syarat mereka; e) Apabila sesuatu yang luar biasa terjadi.

Pertukaran kepentingan diantara para pihak dapat timbul kata sepakat yang berarti keseimbangan telah tercapai walaupun belum tentu terjadi kesamaan, karena menyamakan antara dua hal yang berbeda seperti membedakan antara dua hal yang sama. Sehingga pada akhir negosiasi terdapat dua pilihan, yakni kata sepakat dan tidak sepakat. Jika tercapai kata sepakat maka kerjasama bisa beranjut.

Sebagaimana dijelaskan oleh Rudhi Prasetya, untuk mencari kata sepakat dalam perjanjian atau kontrak, bukan sekedar masalah bagaimana pandai bemegosiasi. Kepandaian bernegosiasi merupakan salah satu faktor keberhasilan. Namun sepiawai apapun penguasaan teknik bernegosiasi, akhirnya yang paling menentukan adalah bargaining position para pihak (Prasetya, 1997). Para pihak hendaknya mencermati dan memperhatikan klausul-klausul dalam kontrak yang sesuai dengan kepatutan (billijkheid) dan keseimbangan (evenwicht), serta menguji keberadaan suatu peranjian melalui asasasas pokok dalam hukum kontrak. Sehingga perbedaan ketidaksamaan atau ketidakseimbangan $\mathrm{da}^{3}$ am berkontrak akan dapat dikaji lebih obyektif.

Transaksi anjak piutang biasanya diawali dengan negosiasi antara perusahaan (Client) dengan lembaga anjak piutang (factoring) yang disesuaikan dengan kebutuhan perusahaan dan dengan fasilitas yang disediakan perusahaan anjak piutang. Apabila perusahaan sudah mengetahui kebutuhannya sejak awal maka akan lebih mempermudah dan mempercepat perjanjian anjak piutang. Pada dasarnya urut-urutan dari perjanjian anjak piutang yang sesuai bagi kehendak para pihak dapat digambarkan sebagai berikut: 1) Pihak kreditur (Client) menjual barang secara kredit untuk jangka waktu pendek dan menengah kepada pihak debitur (customer). Pada tahap ini Client menerbitkan faktur dan customer berjanji akan melunasi faktur tersebut sesuai tanggal jatuh tempo yang ada di $\mathrm{da}^{3} \mathrm{am}$ faktur; 2) Karena kebutuhan akan uang tunai, Client mencari alternatif pembiayaan melalui factor; 3) Client dan factor menandatangani perjanjian anjak piutang, pada perjanjian tersebut factor setuju untuk membeli piutang yang dimiliki Client dengan harga tertentu; 4) Penyerahan dokumen (invoices), daftar customer, syarat-syarat penjualan dan informasi lainnya atas barang atau jasa yang diperjualbelikan kepada factor untuk digunakan sebagai bahan pertimbangan; 5) Factor melakukanpenelitian terhadap yang diberikan dan memutuskan piutang-piutang apa saja yang disetujui atau ditolak; 6) Bagi piutang yang makafactor melakukanpembayaran kepada client; 7) Apabila per- 


\section{Jurnal Cakrawala Hukum, Volume 10 No. 2 Desember 2019}

ISSN PRINT 2356-4962 ISSN ONLINE 2598-6538

janjian anjak piutang tersebut mengatur mengenai fasilitas pembayaran awal, maka factor dapat melakukan pembayaran sebagian besar dari harga pembelian sebagaimana yang telah ditentukan di dalam perjanjian anjak piutang; 8) Apabila perjanjian anjak piutang mengatur mengenai pemberitahuan peralihan dari client kepada factor, maka client akan mengirimkan pemberütahuan kepada customer yang piutangnya telah dialihkan; 9) Setelah jatuh tempo, factor melakukan penagihan kepada customer atau apabila perjanjian anjak piutang mensyaratkan bahwa yang berkewajiban untuk menagih hutang kepada customer adalah client, maka client harus melakukan penagihan atas nama factor; 10) Setelah mendapatkan pelunasan piutang dari customer, factor melakukan pembayaran sisa harga pembelian kepada client; 11) Factor menyerahkan dokumen barang atau jasa berupa dokumen perjanjian dan penanggungan yang berkaitan dengan piutang yang telah dilunasi kepada customer.

Uraian diatas dapat diambil suatu pengertian bahwa, pada dasamya perjanjian anjak piutang adalah kesepakatan tertulis antara factor dan client, dimana factor bersedia untuk melakukan pembelian atau pengambilalihan serta pengurusan atas tagihan jangka pendek dari client dari waktu ke waktu dengan persyaratanpersyaratan tertentu. Perjanjian anjak piutang tidak mempunyai standard baku dan lebih disesuaikan dengan kebutuhan dan kesepakatan bagi kehendak para pihak.

Keuntungan atau manfaat anjak piutang yang diperoleh oleh semua pihak adalah sebagai berikut: 1) Bagi perusahaan Anjak piutang (factor), memperoleh keuntungan berupa fee dan biaya administrasi, membantu menyelesaikan pertikaian diantara kreditur dan debitur, Membantu manajemen pihak kreditur dalam penyelenggaraan kredit.

2) Bagi Kreditur (client), mengurangi resiko kerugian dengan tertagihnya piutang. Perusahaan (client) Tidak ragu dalam penjualan produknya terutama kepada customer baru karena resiko tagihan macet bisa ditanggung bersama dengan lembaga anjak piutang (credit insurance). Memperbaiki sistem administrasi yang semrawut. Anjak piutang dapat memperbaiki sistem penagihan sehingga piutang dapat dibayar tepat saat jatuh tempo dan sebisa mungkin penagihan ini tidak merusak hubungan baik antara perusahaan (client) dengan pelanggannya (customer). Memperlancar kegiatan usaha dengan ditagihnya piutang oleh perusahaan anjak piutang, kreditur dapat berkonsenfrasi keusaha lainnya. Perusahaan yang kesulitan atau kekurangan dana akan segera memperoleh dana tunai sehingga terdapat aliran kas masuk (cash in flow) yang bisa digunakan untuk modal kerja perusahaan. Aliran kas (cash in flow) akan lebih lancar karena perusahaan tidak perlu menunggu pencairan piutang sampai jatuh tempo. 3) Bagi Debitur (customer), memberikan motivasi kepada pihak debitur untuk segera membayar secepatnya, karena ada rasa malu sehingga berusaha semaksimal mungkin untuk segera membayar tagihannya dengan beragai cara.

\section{Simpulan}

Salah satu bentuk bisnis di Indonesia saat ini adalah factoring, yang yang turut dalam meramaikan istilah Indonesia dunia disebut Perjanjian anjak piutang tidak dikenal dalam KUH Perdata maupun KUH Dagang, tetapi dapat hidup dan berkembang karena KUH Perdata kita mengenal sistem terbuka dan asas kebebasan berkontrak yang berpangkal dari adanya kedudukan kedua belah pihak yang seimbang. Namun, dalam praktek, perjanjian anjak piutang berbentuk konfrak baku yang isi dan syarat kontraknya telah ditentukan sepihak oleh factor, maka klien hanya berpeluang untuk menerima atau menolak syarat-syarat yang telah ditentukan tersebut. Asas keseimbangan pada perjanjian anjak piutang (factoring) diberikan penekanan pada posisi tawar para pihak untuk mencapai kesepakatan yang sesuai bagi kehendak para pihak, sehingga pemahaman asas keseimbangan disini terlihat lebih abstrak. 


\section{Asas Keseimbangan dalam Pelaksanaan Perjanjian Anjak Piutang (Factoring)}

Dewi Astutty Mochtar

Asas keseimbangan merupakan asas dalam Hukum Perjanjian di Indonesia yang merupakan kelanjutan dari asas persamaan yang mengkehendaki adanya keseimbangan hak dan kewajiban antara para pihak dalam pelaksanaan perjanjian khususnya perjanjian anjak piutang (factoring). Eksistensi asas keseimbangan dalam pelaksanaan perjanjian anjak piutang (factoring) dijabarkan dalam perumusan hak dan kewajiban para pihak dimana indikator penentu penjabarannya tampak pada posisi seimbang antara hak dan kewajiban masing-masing pihak dalam perjanjian atau kontrak, dimana dalam hukum positif di Indonesia tdak dapat dilepaskan dari sejarah, artinya peraturan perundang-undangan yang berkaitan dengan asas keseimbangan diikuti oleh munculnya dinamika sosial dibelakangnya.

Pengaturan mengenai perjanjiannya mengacu pada KUH Perdata Pasal 1338 Yang merujuk pada asas kebebasan berkontrak, sehingga para pihak dalam membuat aturan perjanjian dilakukan dengan kesepakatan begitu juga jika ada permasalahan yang timbul maka para pihak mencari solusi penyelesaian berdasarkan kesepakatan artinya bisa dilakukan melalui pengadilan negeri maupun melalui lembaga arbitrase.

Hubungan antara asas kebebasan berkontrak yang berlaku di Indonesia dengan segala pembatasannya adalah sesuai dengan pemikiran beberapa tokoh hukum yang sangat menjunjung tinggi moralitas dan keseimbangan serta tetap menghendaki adanya intervensi dari pemerintah. Melalui anjak piutang perusahaan akan memungkinkan untuk memperoleh sumber pembiayaan secara mudah dan cepat. Disamping itu perusahaan bisa meminta staf ahli dari lembaga anjak piutang untuk mengelola administrasi penjualan secara kredit termasuk melakukan penilaian terhadap calon debitur (customer) yang baik.

Belum adanya aturan spesifik yang mengatur tentang kegiatan anjak piutang (factoring) di Indonesia juga mempengaruhi belum berkembangnya anjak piutang sebagai alternatif pembiayaan bagi dunia usaha. Sampai saat ini baru ada Peraturan Presiden Nomor 9 Tahun 2009 tentang Lembaga Pembiayaan dan peraturan Menteri Keuangan Nomor 84/PMK012/2006 tentang Perusahaan pembiayaan yang dipakai acuan oleh pelaku kegiatan pembiayaan Anjak Piutang.

Sasaran yang ingin dicapai adalah memberikan perlindungan hukum yang seimbang kepada factor, klien, dan customer, pembatasan kebebasan berkontrak dapat dilakukan dengan dua cara yaitu, Pertama, menyempurnakan kaidah-kaidah dalam buku 111 KUH Perdata atau membuat undang-undang tentang perikatan dan undangundang tentang hukum kontrak (termasuk kontrak baku). Kedua, membuat beberapa undang-undang yang khusus mengenai suatu aspek tertentu seperti undang-undang mengenai anjak piutang.

\section{Daftar pustaka}

Badrulzaman, Mariam Darus 2001. Kompilasi Hukum Perikatan. Bandung. Citra Aditya Bakti.

Budiono, Herlien. 2011. Ajaran Umum Hukum Perjanjian dan Penerapannya di Bidang Kenotariatan. Bandung. Citra Aditya Bakti.

Hernoko, Agus Yudha. 2010. Hukum Perjanjian Asas Proporsionalitas Dalam Kontrak. Yogyakarta. Liberty.

Mertokusumo, Sudikno. 1985. Hukum Acara Perdata Indonesia. Liberty. Yogyakarta.

Mochtar, Dewi Astutty. 2008. Aspek-Aspek Hukum Bisnis dan Hukum Ekonomi. Malang. Bayumedia Publising.

Raharjo, Satjipto. 2000. Ilmu Hukum. Bandung. Citra Aditya Bakti.

Subekti, 1983. Hukum Perjanjian. Jakarta. Internusa.

Wisnuwardhani, D. (2018). Tanggung jawab koperasi simpan pinjam terhadap jaminan milik pengurus yang di jaminkan hutang koperasi. Jurnal Cakrawala Hukum, 9(1), 21-30. doi:10.26905/ idjch.v9i1.2112. 